\title{
FINANCIAL POLICY STRATEGY IN INCREASING ECONOMIC VALUE ADDED ON MSMES IN MEDAN CITY
}

\author{
Sugiharto $^{1}$, Linda Tripure Maas ${ }^{2}$, Isfenti Sadalia ${ }^{3 *}$, Irada Sinta ${ }^{4}$ \\ ${ }^{1.2,3}$ Postgraduate School Department of Management, Universitas Sumatera Utara, Indonesia. \\ ${ }^{4}$ Faculty of Agriculture, UniversitasMalikussaleh, Indonesia.
}

Corresponding Author: isfenti@usu.ac.id

\begin{abstract}
The global Covid-19 pandemic certainly has an impact on various sectors, especially in the economic sector and of course also has a significant impact on tourism, the trade sector, industry including Micro, Small and Medium Enterprises (MSMEs) in Indonesia. Creative products have great potential to be able to deliver the city that has the industry into an advanced and independent creative economy city. The use of information technology for business resource management for creative products is still under-attentioned, which in turn has administrative, financial, process, and access to banking and financial institutions weaknesses. This study aims to formulate a strategy to increase added value for the MSME sector of North Sumatra Province, namely the Economic Value-Added method and implement efforts to cooperate with the Indonesia Stock Exchange through the mechanism of acceleration boards and Initial Public Offering (IPO) to obtain long-term financing facilities and introduce MSME business unit to the wider community into a medium-class public company. This scientific research also aims to provide recommendations for sustainable strategies for the MSME sector, especially in the province of North Sumatra in running a business amidst the Covid-19 pandemic. This type of research is qualitative research using a mix method by conducting interviews with the target population, namely 200 Micro, Small and Medium Enterprises spread in North Sumatra Province and formulating a model for increasing MSME productivity with the introduction of the acceleration board method and collaborating with the Indonesia Stock Exchange in the coaching process. In this study, a focus group discussion will be held by inviting local officials from related offices of North Sumatra province and academics to provide input in completing the strategy development model for increasing MSME productivity by focusing on the Economic value-added method. The outputs of this research are publications of reputable international journals, international proceedings, and reference books for ISBN certified research results with TKT level 3.
\end{abstract}

Keywords: Economic value added, MSME, IPO

\section{INTRODUCTION}

The global Covid-19 pandemic certainly has an impact on various sectors, especially in the economic sector. This economic impact is not only felt domestically, but also globally. The International Monetary Fund (IMF) projects that the global economy will grow at minus $3 \%$. This of course also has a significant impact on tourism in Indonesia, the trade sector, and the industrial sector, including MSME business actors. Based on the latest data dated May 4, 2020, there have been 11,192 cases of COVID-19 in Indonesia.

The direct impact of covid-19 has been seen from the occurrence of massive layoffs in several MSMEs and the closure of several businesses which have an impact on the layoff of 
employees. According to a report from the Organization for Economic Co-operation and Development (OECD), this pandemic is affecting the economy from both supply and demand sides. On the supply side, MSMEs reduce the supply of raw materials and unhealthy labor and supply chains are also experiencing constraints (OECG, 2020). Data from the Ministry of Cooperatives and Small and Medium Enterprises shows that in 2018 there were 64,194,057 MSMEs in Indonesia and employed 116,978,631 workers. Indonesia is dominated by MSME actors who are the backbone of the national economy which will have a serious impact not only on aspects of their production and income, but also on the number of workers that must be reduced due to this pandemic (Pakpahan, 2020).

This is the basis of the urgency that must be done to be able to increase the productivity of MSMEs in the midst of the covid-19 pandemic so that later they can help MSMEs in the process of flexibility and surviving in the face of this pandemic due to several things such as the low level of digitalization, difficulties in accessing technology and a lack of understanding about technology. survival strategy in business (OECD, 2020). MSMEs are required to be able to adapt to existing business developments because businesses that are able to survive are businesses that are responsive to the times.

One indicator of MSME progress is being able to properly finance short-term operations, then MSMEs are also required to continue to provide product innovation and adapt it based on market demand and cross-cultural conditions of the local community. An indicator of the ability to survive in business competition for the MSME category is if it is able to increase the Economic Value Added (EVA) of the business. With EVA, MSME owners only reward activities that add value and discard activities that damage or reduce the overall value of an MSME. Value added activities can be separated from non-value added activities based on the value added assessment process.

As an effort to support the growth and sustainable Corporation of MSMEs in North Sumatra, the researchers provided assistance and facilitated working capital loans for MSMEs in order to be able to develop products and improve the quality of their production output. The research stage will be accompanied by the implementation of public discussion activities and special training for MSMEs in order to understand the application of the economic value added model with the acceleration board method, namely offering cooperation in the form of a capital portion to open investors through an initial public offering (IPO) on the Indonesia Stock Exchange. The Focus Group Discussion will be attended by stakeholders from the Indonesia Stock Exchange and academics.

\section{LITERATURE REVIEW}

\subsection{Micro small and Medium Enterprises}

Micro, Small and Medium Enterprises (MSMEs) have different definitions in each literature according to several agencies or institutions and even laws. In accordance with article 1 of Law No. 20 of 2008 concerning Micro, Small and Medium Enterprises, what is meant by Micro, Small and Medium Enterprises are: 
1 Micro-enterprises are productive businesses owned by individuals and/or individual business entities that meet the criteria for Micro-enterprises as regulated in this Law.

2 Small business is a productive economic business that stands alone, which is carried out by individuals or business entities that are not subsidiaries or not branches of companies that are owned, controlled, or become part either directly or indirectly of medium-sized businesses or large businesses that meet the business criteria. small as referred to in this Law.

3 Medium Enterprises are productive economic businesses that stand alone, which are carried out by individuals or business entities that are not subsidiaries or branches of companies that are owned, controlled, or become a part either directly or indirectly with Small Businesses or Large Businesses with total net assets or annual sales proceeds as regulated in this Law.

\subsection{Economic Value Added}

EVA (Economic Value Added) is a measure of the actual profit of an MSME in the current year, the EVA value shows the actual remaining profit after the MSME net profit is reduced by all costs of capital including the cost of equity. According to Brigham and Houston (2009), EVA is an estimate of the actual economic profit of the business for the year concerned. EVA reflects the profit remaining after the cost of all capital, including the reduction of equity capital (Young \& O'Byrne, 2001). The notion of EVA is based on the notion of economic profit, which states that wealth is only created when an MSME includes operating and capital costs. In this narrow sense, EVA is really only an alternative way of assessing MSME performance. Financial performance appraisal is measured by the following provisions (Rudianto, 2006):

1. If EVA > 0, then the financial performance of MSMEs can be said to be good, so that there is a process of changing their economic value.

2. If $\mathrm{EVA}=0$, then the financial performance of MSMEs is economically in a state of breakeven.

3. If EVA $<0$, then the financial performance of the MSME is said to be less good because the profits obtained do not meet the expectations of the funders, so that there is no additional economic value for MSMEs.

Every MSME certainly wants the value of EVA to continue to increase, because EVA is a fundamental measure of the rate of return on capital (return of capital). The stages to increase the EVA value (Widayanto, 1993), are:

1. Increase profits (profit) without increasing capital.

2. Reducing the use of capital.

3. Invest in high-return projects.

\subsection{Acceleration Board}

Acceleration Board is a Listing Board provided to list shares of Issuers with SmallScale Assets or Issuers with Medium-Scale Assets as referred to in Financial Services 
Authority Regulation Number 53/POJK.04/2017 concerning Registration Statements in the Context of Public Offering and Capital Increase by Granting Rights Pre-order Securities by Issuers with Small-Scale Assets or Issuers with Medium-Scale Assets and have not been able to meet the requirements on the Development Board. By becoming a public MSME whose shares are traded on the Indonesia Stock Exchange, banks or other financial institutions can get to know and trust MSMEs better. At any time, banks can find out the financial condition of MSMEs through various information disclosures announced by MSMEs through the Exchange. Under these conditions.

\subsection{Initial Public Offering}

Initial Public Offering(IPO)or commonly referred to as going public is a condition in which a company first releases its shares for sale to the general public through the Stock Exchange. IPOs offer various advantages for MSMEs in order to develop their businesses, so this method is often used by MSMEs, both small, medium and large scale ones. In the management of the Indonesia Stock Exchange, it was explained that in order to support the growth of MSMEs in Indonesia, the IDX Incubator program was held which is one of the Indonesian Stock Exchange programs to provide knowledge to MSMEs regarding IPOs, legal aspects for start-ups, and various other strategic information.

\subsection{Research Framework}
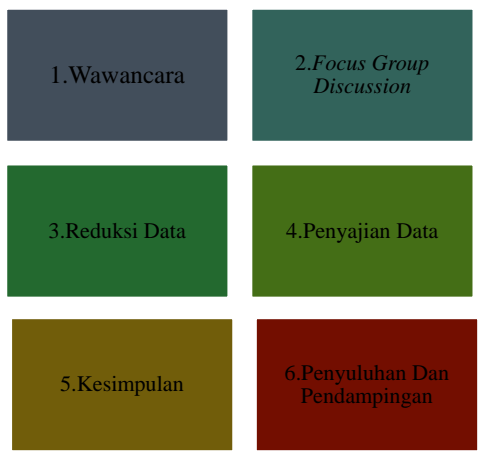

Figure 1. Research Framework

\subsection{Roadmap Study}

The following is a research roadmap for the Strategy for Increasing MSME productivity through Economic Value Added: 


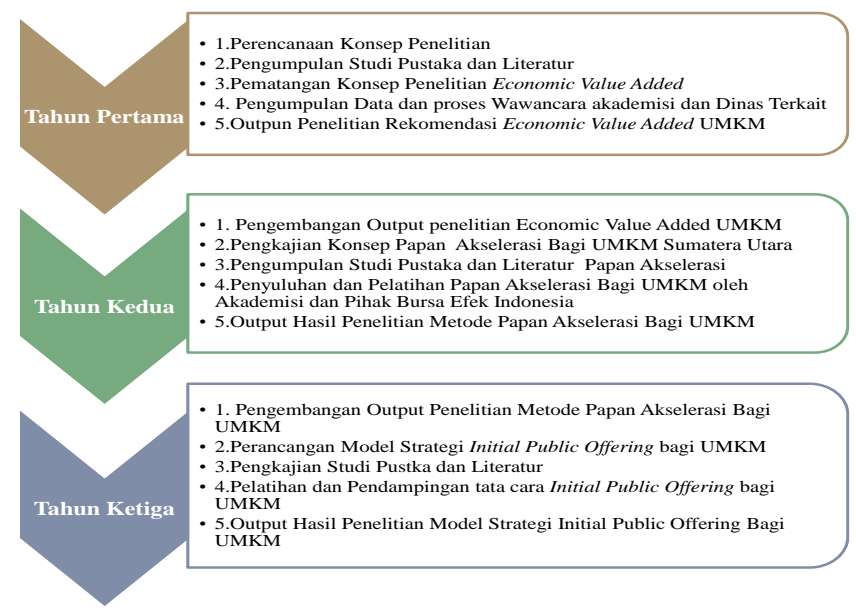

\section{Figure 2. Road Map of Research on Acceleration Board assessment and Initial Public Offering Strategy Model for MSMEs}

\subsection{Research Flowchart}

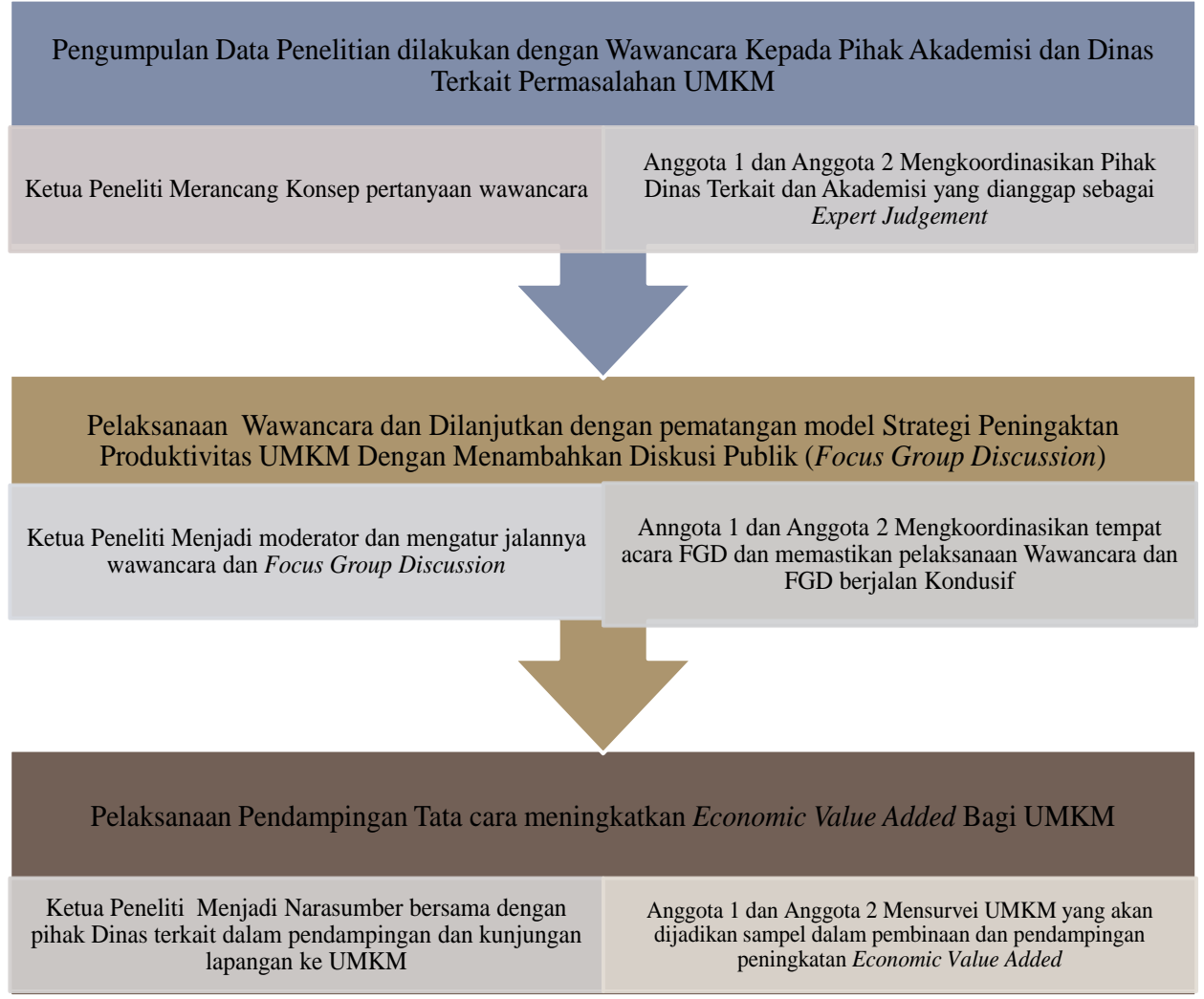

\section{Figure 3. Research Flowchart}

\section{REASEARCH METHODOLOGY}

\subsection{Types of Research}

This type of research is descriptive quantitative and descriptive qualitative (mixed method). Quantitative and qualitative descriptive, namely observations and critical 
investigations to obtain precise information on a particular problem and object in a particular community group area or location will be studied or described or described a situation as clearly as possible without any treatment of the object under study.

The type of data used in this research is primary data obtained from Interviews and Public Discussions (Focus Group Discussions) which were carried out by inviting resource persons from academics who are experts in the field of entrepreneurship and the Related Offices in North Sumatra Province as well as Expert Judgments with backgrounds as MSME entrepreneurs. who have been successful and direct assistance for MSME business actors from the Indonesia Stock Exchange.

\subsection{Population and Sample}

The population of this study is all MSME Business Actors in North Sumatra Province, which are summarized based on the City district area with a target population of 200 North Sumatra MSME Business Actors which are used as research samples.

\subsection{Research Method}

This research uses triangulation method. Data triangulation is a technique of checking the validity of data using something else (Moleong, 2017). This study uses triangulation of sources by means of researchers comparing and re-correcting the degree of trust in information or interview results obtained from research interviews (Moleong, 2017). The validity and credibility of the data was achieved by comparing the results of the interview with a document related to the results of the observations that had been made.

\subsection{Organizational Structure of the Proposing Team and Division of Tasks}

\begin{tabular}{|c|c|c|c|c|}
\hline No. & Name /NIDN/NIP & Faculty/Unit & $\begin{array}{l}\text { Knowledge } \\
\text { field }\end{array}$ & Job description \\
\hline 1 & $\begin{array}{l}\text { Dr. Ir Sugiharto, MM, } \\
\text { IPU/ NIDN } \\
0020035405\end{array}$ & $\begin{array}{l}\text { Faculty of } \\
\text { Engineering }\end{array}$ & $\begin{array}{l}\text { Industrial } \\
\text { Engineering }\end{array}$ & $\begin{array}{l}\text { 1. Making research } \\
\text { phenomena } \\
\text { 2. Pre survey research } \\
\text { 3. Data retrieval and } \\
\text { analysis } \\
\text { 1. Research report } \\
\text { writing }\end{array}$ \\
\hline 2 & $\begin{array}{l}\text { Dr. dr. Linda Tripure } \\
\text { Maas/ NIDK } \\
0019106702\end{array}$ & $\begin{array}{l}\text { Graduate } \\
\text { School }\end{array}$ & Public health & $\begin{array}{l}\text { 2. Prepare research } \\
\text { proposals } \\
\text { 3. Carry out data collection } \\
\text { 4. Perform data tabulation } \\
\text { 5. Processing data }\end{array}$ \\
\hline
\end{tabular}




\section{RESULT AND DISCUSSION}

\subsection{MSMEs in Indonesia}

MSME is a line of business that has proven to be able to survive the crisis in 1997/1998 (Ibrahim and Verliyantina, 2012). Rahmawati and Puspasari (2017) say that MSMEs are strong, dynamic, and efficient businesses so that they can encourage the progress of the national economy. MSMEs, which usually operate in the domestic economy, do not depend on imports, and have unique products, make MSMEs a competitive advantage (Rahmawati and Puspasari, 2017). In addition, MSMEs are also a business line that dominates the Indonesian market. The number of MSMEs in Indonesia reaches more than $90 \%$ of the total business units (MSMEs and Large Enterprises). In addition, MSMEs also absorb a much larger workforce than Large Business Units. The number of MSMEs and the absorption of labor with a high percentage make MSMEs one of the main players in driving the domestic economy in Indonesia. This is confirmed by the fact that MSMEs are the largest contributor to Gross Domestic Product (GDP), which amounted to $60.42 \%$ in 2018. This reflects Indonesia's dependence on MSME growth (Ibrahim and Verliyantina, 2012). Furthermore, Ibrahim and Verliyantina (2012) also said that MSMEs are a determining factor for economic development in Indonesia.

\section{Tabel 4.1 Jumlah UMKM di Indonesia}

\begin{tabular}{rrcrr} 
& $\mathbf{2 0 1 7}$ & $\mathbf{2 0 1 8}$ & $\mathbf{2 0 1 9}$ & $\mathbf{2 0 2 0}$ \\
\hline Micro small and Medium & $59,262,772$ & $61,651,177$ & $62,922,617$ & $64,194,057$ \\
Enterprises & & & & \\
Micro business & $58,521,987$ & $60,863,578$ & $62,106,900$ & $63,350,222$ \\
Small business & 681,522 & 731.047 & 757,090 & 783,132 \\
Medium Enterprise & 59,263 & 56.551 & 58,627 & 60,702 \\
Big business & 4.987 & 5.370 & 5.460 & 5.550 \\
\hline
\end{tabular}

Source: Ministry of Cooperatives and Small and Medium Enterprises

\subsection{Micro, Small and Medium Enterprises in Medan City}

Micro, Small and Medium Enterprises (MSMEs) persist and contribute greatly to Economic Development in Indonesia. In realizing prosperity, the association of entrepreneur institutions is expected to improve strategies that can solve all problems of MSMEs and some of the assembled members can also provide suggestions and constructive criticism to be able to make business concepts better and the meetings are held titled mentoring, seminars to gatherings, can bring together from all circles in the city of Medan both from the Medan city government, academics, the business community and the general public to be able to 
create a cracker spirit which of course can be an important contribution to economic development in the city of Medan.

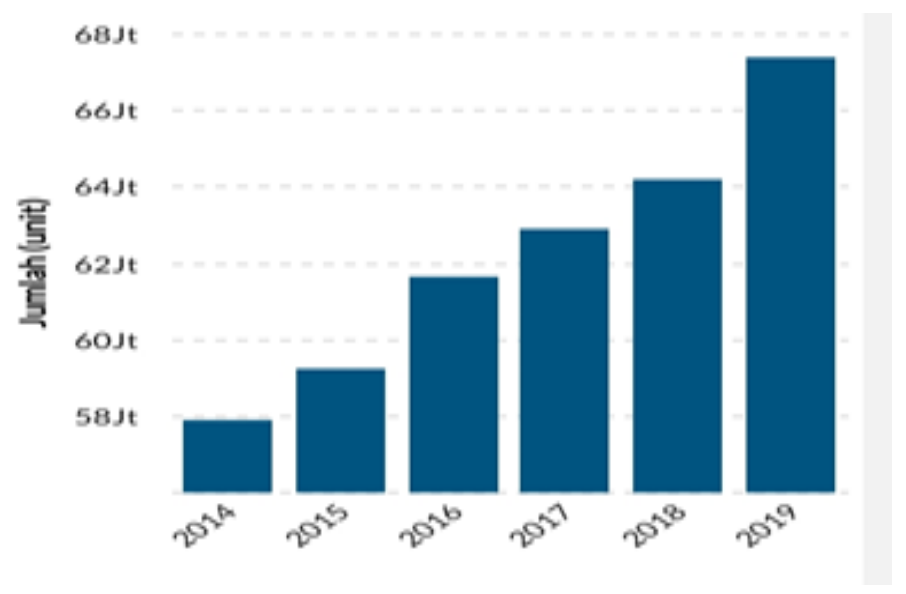

Figure 3. Number of MSMEs in Medan City in 2014-2019

Based on the picture above, it shows that the growth and development of MSMEs has continued to increase over the last five years. This proves that MSMEs are a solid supporter of the economy so that they require very important attention both for the government and business actors.

In accordance with the results of the study, it shows that Micro, Small and Medium Enterprises (MSMEs) are one of the sub-sectors that must receive attention because of their central role in supporting the economy in Indonesia. Around 90\% of the workforce is absorbed in this sector and its contribution to GDP is $60 \%$. If converted into rupiah, the contribution of MSMEs to the Indonesian national economy in 2018 can be said to be quite large with a value of Rp. 8,400 trillion.

\subsection{Problems faced by Small and Medium Enterprises during the Covid 19 Pandemic in Medan City}

The head of the North Sumatran Industry and Trade Agency (Disperindag) Riadil Akhir Lubis stated. The problems faced by MSME business actors during the Corona Virus pandemic include:

1. Experiencing a Drop in Sales

Since the Corona outbreak, of course this has an impact on the purchasing power of the people themselves $\underline{\mathrm{SME} \text { sales }}$ experienced a decline. A total of 774 cooperatives and MSMEs or equivalent to $68 \%$ admitted that their sales had decreased drastically since the Corona Virus outbreak.

2. Difficult to Get Raw Materials

In addition to experiencing a decline in sales, the MSME actors also admitted that they had difficulty getting raw materials due to restricted import activities. It was recorded 
that around 63 cooperatives and SMEs (6\%) complained about the difficulty of raw materials.

3. Distribution Barriers

A total of 111 cooperatives and MSMEs (equivalent to 10 percent) revealed that their distribution was hampered, especially when social distancing was implemented in their respective areas. Of course, this made the delivery or receipt of goods to consumers late.

4. Having Capital Difficulties

It was recorded that as many as 141 cooperatives and MSMEs (12 percent) complained that they had capital problems.

5. Production Barriers

A total of 42 cooperatives and MSMEs (4 percent) revealed that their production has been hampered by the current Corona Virus (Covid-19) outbreak, one of which is the difficulty in obtaining raw materials.

\subsection{Solutions for Strengthening Small and Medium Enterprises during the Covid 19 Pandemic in Medan City}

The solutions offered are:

1. Provision of capital and access to sources and financial institutions. Coupled with the provision of convenience (not complicated) in managing the administration to get capital from financial institutions. It can also be through the effectiveness and efficiency of the People's Business Credit (KUR) program that has been provided by the government.

2. Improve the quality and capacity of HR competencies. Through education and training either carried out by the government or by cooperatives or MSMEs themselves. Improve the marketing ability of MSMEs. Providing education regarding marketing or by opening/recruiting professionals who are experts in marketing.

3. Increase access to business information for MSMEs.

4. Establish mutually beneficial partnerships between business actors (MSMEs, Large Enterprises and BUMN).

5. Doing / making the program goes to goal, that is directly to the goal or target. This is done by providing assistance in terms of capital, concepts, and things needed by cooperatives and MSMEs or by targeting individuals who have an entrepreneurial spirit while maintaining prudential principles and having an investment manager (borrowing the term sharia banking where customers who have been given loans remain fixed). continue to receive supervision or excellent service in processing funds).

\subsection{Strategies for Strengthening Small and Medium Enterprises during the Covid 19 Pandemic in Medan City}

Assauri (2014), explained that the market penetration strategy allows MSMEs to know every strength that arises within their company and compare them with other companies. 
The weaknesses found, need to be evaluated continuously. several market penetration strategies that can be used in relation to efforts to increase market exploitation by the company and at the same time increase sales are:

1. Rapid Skimming Strategy

This strategy is carried out by setting a higher level of sales price and promotional activity. The rapid skimming strategy can only be implemented using the following assumptions:

a. Most of the market potential are not familiar with the product.

b. Prospective consumers who are familiar with the product will be interested in owning the product and have the ability to pay the asking price.

c. Companies face potential competition and aim to build brand preferences.

2. Low Skimming Strategy

This strategy is carried out by setting high sales prices and low promotional activities. The goal of setting a high selling price is to get as much profit per unit as possible, before competitors enter the market offering the same product. The Low Skimming strategy can only be implemented using the following assumptions:

a. The market area is relatively limited.

b. Most markets are familiar with the product.

c. Prospective consumers are willing to pay the asking price

3. Rapid Penetration Strategy

This strategy is carried out by setting low product prices and high promotional activities. This strategy is carried out with the aim that companies can infiltrate the market and can enter the market as quickly as possible, so that the largest market share can be obtained. The rapid penetration strategy can only be executed using the following assumptions:

a. The market area is relatively large

b. Generally, the market doesn't know the product yet

c. Potential consumers are generally price sensitive

d. The possible threat of competitors is quite large, and

e. The production cost per unit tends to decrease with the increase in the number of production and work experience.

4. Slow Penetration Strategy

This strategy is carried out by setting a low selling price and low promotional activities as well. The low price is intended so that the company can stimulate the market to absorb the product quickly, while on the other hand, the company can keep its promotional costs low, so that the net profit that can be obtained is quite large. elastic, but the promotion is less elastic. The slow penetration strategy can only be executed 
using the following assumptions:

a. The market area is relatively large.

b. Generally the market is very familiar with the product

c. Generally, the out market is very price sensitive.

d. There may be threats from competitors.

\subsection{The Role of Equity Crowdfunding for MSMEs in the Pandemic Period in Medan City: Opportunities for Obtaining Funds and Promotion of MSME Businesses through the Equity Crowdfunding Platform}

MSME is the line of business with the largest number of units. This makes this line of business the backbone of the economy and is the main source of a country's economic growth (Robu, 2013). However, because MSMEs have inherent risks and weaknesses such as weak business planning and limited capital (Eldridge et al., 2019), their development is hampered. MSMEs also have limitations in accessing capital to banks. This limitation is related to the obstacles faced by MSMEs in the city of Medan when applying for credit to banks such as administrative requirements and inflexible banking interest (Nurmalita, 2020).

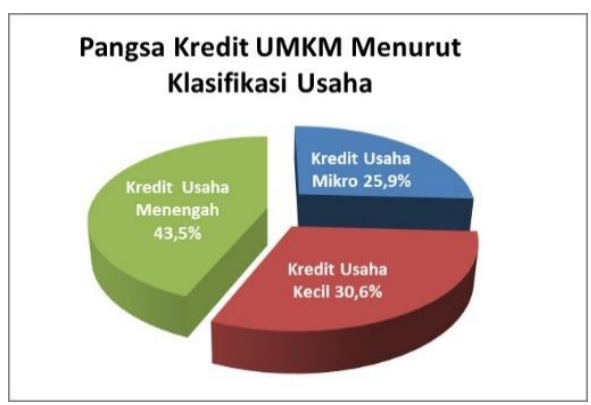

Source: MSME Credit Development Report for Quarter III 2019

Figure 4. Share of MSME Credit by Business Classification

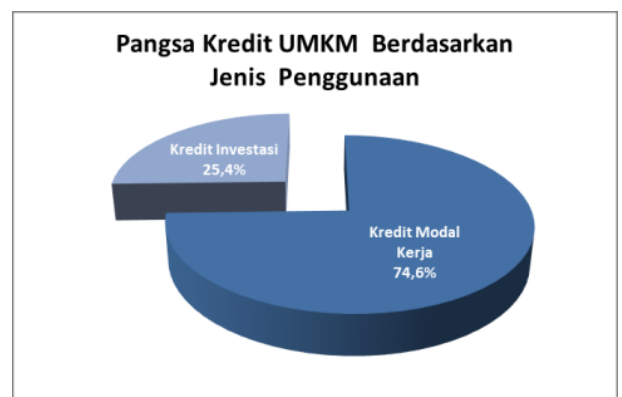

Source: MSME Credit Development Report for Quarter III 2019

Figure 5. Share of MSME Credit by Business Classification 
The MSME Credit Development Report for Quarter III of 2019 shows that the majority of bank credit flows to medium-sized businesses, which is $43.5 \%$. In addition, as much as $74.6 \%$ of these loans were used as working capital by MSMEs. This shows that most MSMEs in Medan City apply for credit to banks for business operational purposes such as purchasing raw materials and production processes. This data also provides an overview of the needs of MSMEs related to additional capital proposed through the banking credit mechanism.

Equity crowdfunding requires that the business entity wishing to issue shares is not a newly established entity. This means that the funds obtained by the issuing entity are not used to start a business, but to expand or develop its business. Santara (PT Santara Daya Inspiratama), the first equity crowdfunding company licensed by the OJK in Indonesia, requires the issuer of shares to be a business that is already running, has customers, and is already profitable. Santara also requires that the issuing entity has a business that is accountable, has clear governance, and is transparent. Publishing entities are also expected to have long-lived businesses. This is required to minimize the investment risk of potential investors.

In mid-October 2020, there were 71 business entities that had issued shares on the Santara Platform (Santara.co.id) and there were 40 business entities that issued on the Bizhare Platform (Bizhare.id). This number is still much smaller than the total number of MSMEs in Medan City. This indicates that the utilization of the equity crowdfunding platform by MSMEs has not been maximized. In fact, apart from obtaining funds, the crowdfunding platform can provide other benefits for business entities because business entities can publish their business profiles so that they can be used to raise trademarks and sales performance.

Research conducted by Eldridge et al., (2019) shows that equity crowdfunding is proven to increase growth opportunities for MSMEs. The equity crowdfunding platform encourages the growth of MSMEs through the impact of the platform on product and brand growth processes (Eldridge et al., 2019). Prospectuses and business profiles published by MSMEs on the equity crowdfunding platform can be a means of promoting the businesses and products of these MSMEs. If used properly, this mechanism can encourage the popularity of the MSME business so that apart from increasing customers, it can also increase its business value. Equity crowdfunding gives business actors the opportunity to test products, develop brands, build a strong customer base, or turn customers into investors (Estrin et al., 2018).

Each equity crowdfunding organizer through various social media owned will display the business profile of each MSME, this will also help increase the popularity of MSMEs and their products in the eyes of the public. Eldridge et al., (2019) say that MSMEs that successfully take advantage of this impact can connect to the equity crowdfunding network and stakeholders. This mechanism not only saves MSMEs from limited funding but also uses them to improve business performance and growth (Eldridge et al., 2019). This is an 
advantage that MSMEs do not get when applying for credit to banks.

In the face of a pandemic, MSME business players must find a strategy to maintain their business. Changes or additions to product lines are one method that is widely used by MSMEs. Changes or additions to this product line of course require additional capital. Business expansion such as opening a new branch also requires significant additional capital. Several MSMEs who are engaged in the food and beverage business admit that there has been an increase in product demand through online motorcycle taxi applications during the pandemic. This is one of the backgrounds for the plan to open a new branch that will be carried out by the business owner. This condition has also made several MSMEs in the food and beverage business line to raise funds through the equity crowdfunding platform.

By looking at the prospectuses of MSMEs that issued their shares in Santara, there are several MSMEs who wish to use the proceeds from their share offering on the equity crowdfunding platform to open new branches during the pandemic. Some of these business entities are Kue Balok Mang Salam, Kopi Loer, Nasi Peda Pelangi, Baso Aci Akang, Jokopi, and Warung Layar Touch. This indicates that there are still many MSMEs that have bright business prospects. Here, crowdfunding is an alternative funding that can be chosen to generate business during the pandemic.

Not only the government, each MSME must also develop short-term and long-term strategies to get through the pandemic. Short-term strategies such as adding new product lines by making products that are relevant to the needs of the community during a pandemic are one of them. In addition, the change in transaction methods from offline to online is another strategy. Adjustment of cash flow management is also a short-term strategy that can be done to improve business efficiency, adjusting to the current economic environment. Furthermore, as a long-term strategy, MSME actors must prepare a business roadmap going forward. The digitization of MSMEs is an unavoidable phenomenon. The pandemic has accelerated the evolution of business. MSMEs that can survive are MSMEs that can innovate and adapt to all kinds of conditions that occur. Investments to implement business adaptation and innovation must be supported with careful consideration. The prospectus prepared by MSMEs to be published through the equity crowdfunding platform should also reflect the long-term business prospects, so that potential investors have a view on the future of the MSMEs. Equity crowdfunding should be used not only to save MSMEs from the pandemic storm, but also as a means to support the survival and progress of MSMEs in the long term. Investments to implement business adaptation and innovation must be supported with careful consideration. The prospectus prepared by MSMEs to be published through the equity crowdfunding platform should also reflect the long-term business prospects, so that potential investors have a view on the future of the MSMEs. Equity crowdfunding should be used not only to save MSMEs from the pandemic storm, but also as a means to support the survival and progress of MSMEs in the long term. Investments to implement business adaptation and innovation must be supported with careful consideration. The prospectus prepared by MSMEs to be published through the equity crowdfunding platform should also reflect the long-term business prospects, so that potential investors have a view on the future of the 
Financial Policy Strategy In Increasing Economic Value Added On MSMES In Medan City DOI: $10.54443 /$ ijebas.v1i2.112

MSMEs. Equity crowdfunding should be used not only to save MSMEs from the pandemic storm, but also as a means to support the survival and progress of MSMEs in the long term.

\subsection{Novelty and Output}

In the research process to support the added value of Medan City MSMEs, the research team and related agencies as well as MSME business actors carried out various forms of efforts and coordination in the midst of the Covid-19 pandemic, including one of them holding a Focus Group Discussion on the acceleration of MSME funding in Medan City. The following is the formulation of the policy recommendations that were born in the FGD activities and are called "Smooth Economic Value Added By Equity Crowdfunding" or SEVAF, which is a policy recommendation in providing opportunities for MSME business actors to gain access to funding through an acceleration model in banking and market financial institutions. capital. based on the results of the Focus Group Discussion in this study, among others:

1. The Office of Cooperatives, Trade and Industry of the North Sumatra Branch as the agency for formulating policies on the scope of MSME Business has approved the special MSME Business Licensing Requirements with a tax rate of $<2.5 \%$ Total Reveneu.

2. The Financial Services Authority (OJK) for the Northern Sumatra Region (SUMBAGUT) As a banking and capital market supervisory agency, it fully supports the process of accelerating MSME business funding by providing a Special ACCESS Card for MSMEs with business licenses to participate in the Acceleration Board funding program.

3. Indonesia Stock Exchange Representative of North Sumatra As an institution providing the Acceleration Board service, it opens the widest opportunities for every MSME business that has a license to obtain Acceleration Board funding by providing education to business actors and creating a special program "Special Education for MSMEs Initial Public Offering", as well as facilitate all MSME business actors in the process of issuing initial shares on the Acceleration Board service by conducting matching funds between investors and MSME business actors.

4. The Directorate General of Taxes for the Region of North Sumatra As the official tax collection agency in Indonesia will consider the policy recommendations that are formulated, then after that it will be adjusted to the follow-up of the Acceleration Board program for MSME business actors, especially the North Sumatra Region and Medan City in an effort to increase the Economic Value Added MSMEs in the time of the covid-19 pandemic. 


\subsection{Types of Service in "Smooth Economic Value Added By Equity Crowdfunding" (SEVAF)}

\section{Donation Based}

As the name implies, donors who deposit their capital do not receive any compensation from the proposed project. Usually on a donation basis, crowdfunding is intended for non-profit projects such as building orphanages, schools, etc.

\section{Reward Based}

In this type, those who submit proposals usually provide offers in the form of gifts or other rewards in the form of goods, services or a right, not providing a share of the profits derived from the project. This type of crowdfunding is usually intended for projects from the creative industry such as games, where the donors who fund the project will be given interesting features from the games.

\section{Equity Based}

The concept is the same as shares, where the money deposited will become equity or part ownership of the company in exchange for dividends.

\section{CONCLUSION AND SUGGESTION \\ 5.1 Conclusion}

The conclusions in this study are as follows:

1. The problems faced by Small and Medium Enterprises during the Covid 19 pandemic are as follows:

a. Experienced a $68 \%$ Decrease in Sales

b. Difficult to Get Raw Materials. It was recorded that around (6\%) complained about the difficulty of raw materials.

c. Distribution Barriers. A total of 111 cooperatives and MSMEs (equivalent to 10 percent) revealed that their distribution was hampered

d. Experiencing Capital Difficulties. It was recorded that as many as 141 cooperatives and MSMEs (12 percent)

e. Production Delays. A total of 42 cooperatives and SMEs (4 percent).

2. Solutions for Strengthening Small and Medium Enterprises during the PandemicCovid 19 in Medan City

a. Provision of capital and access to sources and financial institutions.

b. Improve the quality and capacity of HR competencies.

c. Increase access to business information for MSMEs.

d. Establish mutually beneficial partnerships between business actors (MSMEs, Large Enterprises and BUMN). 
Financial Policy Strategy In Increasing Economic Value Added On MSMES In Medan City DOI: $10.54443 /$ ijebas.v1i2.112

e. Doing / making the program goes to the goal, that is, straight to the goal.

3. Strategy for Strengthening Small and Medium Enterprises during the COVID-19 Pandemic in Medan City

a. Rapid Skimming Strategy, setting a higher level of sales price and promotional activity.

b. Low Skimming Strategy, setting high sales prices and low promotional activities.

c. Rapid Penetration Strategy, setting low product prices and high promotional activities.

d. Slow Penetration strategy, setting a low selling price and low promotional activities as well.

4. This study aims to identify the role of equity crowdfunding in encouraging MSMEs to survive the pandemic. This research was motivated by the serious impact caused by the pandemic on the survival of MSMEs.

5. Equity crowdfunding be an option to save MSMEs from bankruptcy through the opportunity to get additional funds. Equity crowdfunding brings together the issuer of shares with potential investors. In addition, through the equity crowdfunding platform, business entities can promote their business so that they can boost their business performance and value. This aspect is an added value for the equity crowdfunding system compared to bank credit. The prospectus issued by the share issuing entity (MSME) through the equity crowdfunding platform provides an opportunity for the entity to promote its business and products to the wider public, especially potential investors so as to increase the value of the entity. Therefore, this platform can be a new option to save and increase MSME businesses in the midst of a pandemic.

\section{REFERENCES}

Apriliana, ED (2019). The Development Strategy of Batik SMEs to Increase the Competitiveness of Semarangan Batik in Batik Village, Semarang City. Retrieved from https://lib.unnes.ac.id/35755/.

Assauri, S. (2014). Basic Marketing Management, Concepts and Strategies. Jakarta: Raja Grafindo Persada.

EF Brigham,JF Houston., (2007), Fundamentals of Financial Management. Eleven Edition. Thomson

Southwestern.https://www.academia.edu/download/61207082/epdf.pub_fundamental s-of-financial-management-eleventh-edit20191113-119089-1i6ldfi.pdf.

Eldridge, D., Nisar, TM, \& Torchia, M. (2019). What impact does equity crowdfunding have on SME innovation and growth? An empirical study. Small Business Economics. https://doi.org/10.1007/s11187-019-00210-4 
Estrin, S., Gozman, D., \& Khavul, S. (2018). The evolution and adoption of equity crowdfunding: entrepreneur and investor entry into a new market. Small Business Economics, 51(2), 425-439. https://doi.org/10.1007/s11187-018-0009-5

Ibrahim, N., \& Verliyantina. (2012). The Model of Crowdfunding to Support Small and Micro Businesses in Indonesia Through a Web-based Platform. Procedia Economics and Finance, 4(Icsmed), 390- 397. https://doi.org/10.1016/s2212-5671(12)00353-x

Kemenkopuk. (2018). Data Development of Micro, Small, Medium Enterprises (UMKM) and Large Enterprises (UB) in 2017-2018.

KUR. (2020). KUR Realization Data until July 31, 2020. Accessed from https://kur.ekon.go.id/realisasi_kur/2020/7 on October 24, 2020

Moleong., (2017), Research methodology. https://core.ac.uk/download/pdf/200764660.pdf

Nurmalita, L. (2020). Equity Crowdfunding Policy in the Context of Funding Innovation for Micro, Small and Medium Enterprises (MSMEs). Airlangga Journal of Innovation Management, 1(1), 115. https://doi.org/10.20473/ajim.v1i1.20179

OECD. "SME Policy Responses." Retrieved 23 April 2020.https://read.oecdilibrary.org/view/?ref=119_119680di6h3qgi4x\&title=Covid19 SME_Policy_Responses.

Pakpahan (2020), COVID-19 and Implications for Micro, Small and Medium Enterprises. http://103.36.68.33/index.php/JurnalIlmiahHubunganInternasiona/article/download/3 $\underline{870 / 2903 .}$.

Rahmawati, T., \& Puspasari, OR (2017). Implementation of Sak Etap and Quality of MSME Financial Reports Related to Access to Banking Capital. Journal of Accounting Studies, 1(1), 49-62. https://doi.org/10.33603/jka.v1i1.510

Robu, M. (2013). The Dynamic and Importance of SMEs in Economy. The USV Annals of Economics and Public Administration, 13(1), 84-89.

Ruslan., (2010), Methodquantitative, qualitative \& combined research https://core.ac.uk/download/pdf/296974333.pdf

SNSarfiah. et all (2019),MSMEs as Pillars of Building the Nation's Economy. https://jurnal.untidar.ac.id/index.php/REP/article/view/1952 WLHardilawati., (2020), MSME Survival Strategy Amid the Covid-19 Pandemic http://www.ejurnal.umri.ac.id/index.php/jae/article/download/1934/1223

Widayanto., (1993), Analysis of the effect of economic value added (EVA) and financial ratios to Islamic stock returns. http://repository.unikama.ac.id/927/1/Jurnal\%20Ekonomi\%20Modernisasi.pdf.

Young., O'Byrne., (2001), Analysis of the Financial Performance of Pulp and Paper Companies That Go Public on the Indonesia Stock Exchange (IDX) Based on Economic Value Added (Eva) Methods, Market Value Added (Mva) and Return On Assets
(Roa).
Period
2011-2015. http://digilib.unila.ac.id/id/eprint/26943http://www.depkop.go.id/uploads/tx_rtgfiles/ SANDINGANDATAUMKM20122017.pdf accessed on, 10-July-2020, 20.45 wib 
Financial Policy Strategy In Increasing Economic Value Added On MSMES In Medan City DOI: $10.54443 /$ ijebas.v1i2.112

https://www.kompas.com/sains/read/2020/05/11/130600623/diumumkan-awal-maret-ahlivirus-corona-enter-indonesia-dari-januari. Accessed on Tuesday, 14-07-2020. 08.30 Wibhttps://medankota.bps.go.id/pressrelease/2019/07/16/70/pertumbuhan-ekonomikotamedantahun2018.html\#: :text=Ekonomi\%20Kota\%20Medan\%20Tahun\%20201 8\%20tumbuh\%20sebesar\% 205\%2C92\%25.,processing\%20by\%2014\%2C61\%25. Accessed on, 15-July-2020. At 09.30 wib www.covid19.go.id accessed in October 2020 